\title{
Serum Electrolyte Changes during Extracorporeal Circulation
}

\author{
A. Yüksel Bozer, M.D., Gürler Ilıçın, M.D., Ali ApıKoĞLu, M.D., \\ Aydín KaramehmetoĞLu, M.D., and Argun Saylam, M.D.
}

\section{SUMMARY}

Serum Na, K, Ca and P levels were determined in 23 cases undergoing open heart surgery during preoperative, early and late postoperative periods. Serum $\mathrm{Mg}$ values were detected in the same manner, also during extracorporeal circulation. Serum $\mathrm{K}, \mathrm{Na}, \mathrm{Cl}$ and $\mathrm{Ca}$ levels decreased during postoperative period. No change in serum $\mathrm{P}$ was observed. Serum $\mathrm{Mg}$ values fell during early postoperative period in 13 cases containing no $\mathrm{Mg}$ in the circuit, but were close to normal in 10 cases where $\mathrm{Mg}$ was added into the priming volume in amount of $2 \mathrm{mEq}$. per 1,000 ml. Ringer's lactate. In both groups serum $\mathrm{Mg}$ values were low during cardiopulmonary bypass. It has been discussed that hemodilution, hyperaldosteronism, hyperparathyroidism and diuretics might be effective in hypomagnesemia in open heart surgery. Hypomagnesemia was thought to participate in the production of postoperative arrhythmias like hypopotassemia, and thromboembolic phenomenon. importance Hence, of addition of $\mathrm{Mg}$ into the circuit was emphasized.

\section{Additional Indexing Words:}

Magnesium metabolism Hyperaldosteronism

Hypomagnesemia Hyperparathyroidism Postoperative arrhythmias

Thromboembolic phenomenon Hypocalcemia solutions are used as a priming volume in the heart lung machines. Changes in blood electrolyte levels are to be watched meticulously during cardiopulmonary bypass and the postoperative period. In this paper, we discussed serum electrolyte values detected in our cases.

\section{Material and Method}

Twenty-three patients are included in this series. Twelve were females and 11 were males. Ages of the patients varied from 18 to 54, making an average of

From the Department of Adult Thoracic and Cardiovascular Surgery and Cardiology, Hacettepe University, Ankara, Turkey.

Received for publication February 17, 1972. 
32. The following operations were performed in these patients:

13 cases........ Mitral valve replacement

7 cases........ Mitral and aortic valve replacements

1 case ......... Pulmonary valvulotomy

All patients had salt free diet, and all were digitalized. Diuretics were not given for 3 weeks' duration before surgery.

Rygg-Kyvsgaard disposable oxygenator and heart-lung machine with DeBakey pumps were used for extracorporeal circulation. Ringer's lactate $20 \mathrm{ml} . / \mathrm{Kg}$. body weight was used for hemodilution. $80 \mathrm{ml}$. of $20 \%$ Mannitol, $20 \mathrm{ml}$. of $\mathrm{NaHCO}_{3}$ and $50 \mathrm{ml}$. of $5 \%$ dextrose solutions were added into the priming volume. Mean duration of extracorporeal circulation was $44 \mathrm{~min}$, changing from 12 to $71 \mathrm{~min}$. Serum $\mathrm{Na}, \mathrm{K}, \mathrm{Cl}, \mathrm{Ca}, \mathrm{P}$ and $\mathrm{Mg}$ were measured photometrically just before operation, just after operation and during the 24th hour postoperatively. Serum Mg levels were also determined during by-pass and measured depending on the photometric method originally improved by $\mathrm{Hill}^{1)}$ and Schachter. ${ }^{1)}$ In 13 cases $\mathrm{Mg}$ was absent in the priming volume, but present in 10 cases in the amount of $2 \mathrm{mEq} . \mathrm{Mg}$ per $1,000 \mathrm{ml}$. Ringer's lactate solution.

\section{RESULTS}

Serum $\mathrm{Na}, \mathrm{Cl}, \mathrm{Ca}$ and $\mathrm{P}$ levels determined throughout this investigation are shown in Table I. Comparison between preoperative and late postoperative values of serum $\mathrm{Na}$ and $\mathrm{Cl}$ yielded a significant fall of these substances during the late postoperative period $(p<0.0005)$. Regarding $K$, a significant decrease in the early postoperative period was observed $(p<0.0005)$. An important loss in serum Ca was present in the early postoperative period $(\mathrm{p}<0.005)$, and this fall became more obvious during the late postoperative

Table I. Mean Value of Serum Electrolytes in Cases of Open Heart Surgery

\begin{tabular}{|c|c|c|c|c|}
\hline Substance & $\begin{array}{l}\text { Preoperative } \\
\text { Value I }\end{array}$ & $\begin{array}{c}\text { Early Postoperative } \\
\text { Value If }\end{array}$ & $\begin{array}{c}\text { Late Postoperative } \\
\text { Value III } \\
\text { (24th hour } \\
\text { Postoperatively) }\end{array}$ & $\begin{array}{l}\text { Comparison } \\
\text { of the Values } \\
\text { Obtained }\end{array}$ \\
\hline $\mathrm{Na}(\mathrm{mEq} / \mathrm{L})$. & $139 \pm 0.57$ & $138 \pm 0.78$ & $134 \pm 0.82$ & $\begin{array}{ll}\text { I-II } & p<0.20 \\
\text { I-III } & p<0.0005\end{array}$ \\
\hline $\mathrm{Cl}$ (mEq./L.) & $101 \pm 0.93$ & $99 \pm 0.72$ & $96 \pm 0.77$ & $\begin{array}{ll}\text { I-II } & p<0.10 \\
\text { I-III } & p<0.0005\end{array}$ \\
\hline $\mathrm{K} \quad(\mathrm{mEq} \cdot / \mathrm{L})$. & $4.40 \pm 0.78$ & $3.70 \pm 0.09$ & $4.30 \pm 0.92$ & $\begin{array}{ll}\text { I-II } & p<0.0005 \\
\text { I-III } & p<0.25\end{array}$ \\
\hline $\mathrm{Ca}(\mathrm{mg} / 100 \mathrm{ml})$ & $9.50 \pm 0.15$ & $8.80 \pm 0.19$ & $8.70 \pm 0.17$ & $\begin{array}{ll}\text { I-II } & p<0.005 \\
\text { I-III } & p<0.0025\end{array}$ \\
\hline $\mathrm{P}$ (mg./100 ml. $)$ & $4.70 \pm 0.26$ & $4.30 \pm 0.16$ & $4.70 \pm 0.17$ & $\begin{array}{ll}\text { I-II } & p=0.10 \\
\text { I-III } p=0\end{array}$ \\
\hline
\end{tabular}


Table II. Mean Serum Magnesium Levels in Cases of Open Heart Surgery (mEq./L.)

\begin{tabular}{c|c|c|c|c|c}
\hline & $\begin{array}{c}\text { Preoperative } \\
\text { I }\end{array}$ & $\begin{array}{c}\text { Operative } \\
\text { II }\end{array}$ & $\begin{array}{c}\text { Early } \\
\text { Postoperative } \\
\text { III }\end{array}$ & $\begin{array}{c}\text { Late } \\
\text { Postoperative } \\
\text { IV }\end{array}$ & $\begin{array}{c}\text { Comparison of } \\
\text { the Values } \\
\text { Obtained }\end{array}$ \\
$\begin{array}{c}\text { Cases containing no } \\
\text { Mg in the circuit }\end{array}$ & $2.40 \pm 0.13$ & $1.68 \pm 0.04$ & $1.91 \pm 0.06$ & $2.37 \pm 0.11$ & $\begin{array}{c}\text { I-II } \mathrm{p}<0.0005 \\
\text { I-III } \mathrm{p}<0.0005 \\
\text { I-IV } \mathrm{p}=0.30 \\
\text { II-III } \mathrm{p}<0.005 \\
\text { I-II } \mathrm{p}<0.0005\end{array}$ \\
$\begin{array}{c}\text { Cases containing* } \\
\text { Mg in the circuit }\end{array}$ & $2.33 \pm 0.12$ & $1.54 \pm 0.05$ & $2.06 \pm 0.14$ & $2.17 \pm 0.15$ & $\begin{array}{l}\text { I-III } \mathrm{p}<0.10 \\
\text { I-IV } \mathrm{p}=0.20 \\
\text { II-III } \mathrm{p}<0.025\end{array}$
\end{tabular}

*: $\mathrm{Mg}$ was added into the priming volume of the circuit in amount of $2 \mathrm{mEq} . \mathrm{Mg}$ per $1,000 \mathrm{ml}$. Ringer's lactate. Ringer's lactate was used $20 \mathrm{ml}$, per each $\mathrm{Kg}$. of body weight.

phase $(p<0.0025)$. Serum $P$ levels could not be demonstrated to be of any importance throughout this investigation.

Serum $\mathrm{Mg}$ levels are displayed in Table II. In cases containing no $\mathrm{Mg}$ in the circuit low levels of this ion were detected during operation and the early postoperative period $(\mathrm{p}<0.0005)$. In patients containing $\mathrm{Mg}$ in the circuit an important fall of this substance in blood serum was only detected during cardiopulmonary bypass $(\mathrm{p}<0.0005)$, despite addition of $\mathrm{Mg}$ into the priming volume. Early and late postoperative values in this group revealed no significance $(p<0.10$ and $p=0.20)$.

\section{Discussion}

Salt restriction in diet is one of the main principles in the medical therapy of cardiac failure. Despite this fact Na containing solutions are still used for hemodilution in open heart surgery. In 1957, Hayes et al. ${ }^{11}$ reported increased excretion of aldosterone and Na retention in the postoperative period resulting from addition of glucose solutions into the priming volume. They also stated that no increase in aldosterone excretion and no Na retention occurred in the postoperative period by the use of $\mathrm{Na}$ containing solutions during operative and postoperative periods. In 1963, Rand et al. ${ }^{11}$ displayed that the use of $\mathrm{Na}$ containing solutions in open heart surgery led to an increase in plasma osmolality, $\mathrm{Na}$ concentrations and urinary excretion of $\mathrm{Na}$ and $\mathrm{K}$ during the early postoperative phase.

In 1968, Neville and Talso' reported that no significant changes were seen in serum $\mathrm{Na}$ and $\mathrm{Cl}$ levels with the use of Ringer's lactate solution in extracor- 
poreal circuit. In 1970, Dieter et al. ${ }^{11}$ found same results. They used 2,500-3,000 ml. of Ringer's lactate containing 325-390 mEq. Na. Late postoperative decrease in $\mathrm{Na}$ and $\mathrm{Cl}$ values was probably due to the postoperative administration of glucose solutions holding no electrolytes.

$\mathrm{K}$ plays important role in the normal function of myocardium. ${ }^{11)}$ Therefore, changes in serum $\mathrm{K}$ levels during cardiopulmonary by-pass is to be followed carefully. Hypopotassemia during extracorporeal circulation has been detected by a number of investigators. ${ }^{12)}{ }^{15}$ ) Various factors have been blamed for the disturbance of this ion, among which respiratory alkalosis due to hyperventilation (during anesthesia), hemodilution, duration of perfusion, hyperaldosteronism, effects of diuretics and penetration of $\mathrm{K}$ into intracellular space are the mostly argued.16), 17) Whatever the real cause is, addition of $\mathrm{K}$ into the circuit is important in the avoidance of postoperative arrhythmias.

Hypocalcemia after cardiopulmonary by-pass, as encountered in our cases, has already been recorded by some observers. ${ }^{91,10)}$ Use of acid citrated bank blood in the early postoperative period, and Ringer's lactate which is not equal to blood serum in $\mathrm{Ca}$ concentrations can be accused for postoperative hypocalcemia. Hence, addition of $\mathrm{Ca}$ into the circuit and careful follow up after acid citrated bank blood transfusions are important.

The effect of extracorporeal circulation on serum $\mathrm{Mg}$ metabolism has been investigated by Sheinman et al. ${ }^{18)}$ in 1968 . In their paper, an important decrease in serum $\mathrm{Mg}$ values during the early postoperative period was reported in cases subjected to $\mathrm{Mg}$ free cardiopulmonary by-pass. In 1970, Dieter et al. ${ }^{10}$ reported similar findings. In 1971, Sheinman et al. ${ }^{19}$ presented low serum $\mathrm{Mg}$ levels in the early postoperative period in 5 of the 8 patients, despite the addition of $\mathrm{Mg}$ into the priming volume. They stated that hemodilution and increase in renal clearance of $\mathrm{Mg}$ could be possible factors responsible for this. Although occurrence of hypomagnesemia in spite of adding physiologic doses of $\mathrm{Mg}$ into the circuit has been thought to be primarily due to hemodilution, other theories regarding this subject can be proposed.

The hypothesis of the occurrence of magnesuria reminds us relationships between $\mathrm{K}, \mathrm{Mg}$ and aldosterone. Hyperaldosteronism due to hypoperfusion of body tissues during by-pass has already been presented as a factor producing hypopotassemia. ${ }^{101}$ Aldosterone causes magnesuria ${ }^{20}$ and an impairment in intestinal excretion of $\mathrm{Mg},{ }^{21)}$ thus resulting in hypomagnesemia. Hypomagnesemia itself activates renin-angiotensin II system and hyperaldosternoism is developed. ${ }^{20)}$ Because of the above reasons, hyperaldosteronism may be responsible for hypomagnesemia in open heart surgery by increasing magnesuria; and the resulting hypomagnesemia causes an increase in aldosterone excretion, thus establishing a circulus viciosus. Hypopotassemia also takes 
place during this cycle.

Secondary hyperparathyroidism developing as a result of hypocalcemia may also take a part in the production of hypomagnesemia. In fact, intracellulary $\mathrm{Mg}$ levels decrease in cases of hyperparathyroidism. ${ }^{22}$. Although the relationship between $\mathrm{Mg}$ and parathormone is not clear, it is commonly accepted that parathormone increases renal absorption of $\mathrm{Mg}$, but also causes excretion of $\mathrm{Mg}$ from bones, which may result in a negative balance of body $\mathrm{Mg}$ values. ${ }^{201,23)}$ Therefore, secondary hyperparathyroidism may participate in hypomagnesemia during extracorporeal circulation.

Diuretics may also cause hypomagnesemia by creating magnesuria. ${ }^{24), 25)}$ Mannitol, added into the circuit in our cases might be such a factor by causing osmotic diuresis.

Increase in digitalis toxicity in presence of hypomagnesemia is a known fact today. ${ }^{24,}$, 25) Hence, hypomagnesemia may contribute to the production of postoperative arrhythmias like hypopotassemia. Sheinman et al. ${ }^{19)}$ presented low incidence of postoperative arrhythmias by addition of $\mathrm{Mg}$ into the circuit. Our findings also support this observation.

It has already been stated that $\mathrm{Mg}$ activates fibrinolysis ${ }^{28)}$ and latens thrombin generation. ${ }^{29}$ In 1967, Durlach ${ }^{30}$ and in 1969 Dupont $^{31)}$ reported cases of thrombo-embolic phenomenon due to hypomagnesemia. Therefore, the use of $\mathrm{Mg}$ as a prophylactic measure in the prevention of postoperative and postpartum thrombo-embolic disorders is still open to discussion. ${ }^{321}$ In our cases no thrombo-embolic phenomenon has been observed during the 24 hours postoperatively.

We believe, addition of $\mathrm{Mg}$ into the extracorporeal circuit has certainly a beneficial prophylactic effect in the prevention of early postoperative arrhythmias after open heart surgery.

\section{REFERENCES}

1. Beall, H. C., Jr., Yow, E. M., Bloodwell, R. D., Hallman, G. L., and Cooley, D. A.: Arch. Surg. 94: 567, 1967.

2. Neville, W. E., Thomason, R. S., and Hirsch, D. M.: Arch. Surg. 93: 715, 1966.

3. Evans-Prosser, C. D. G., Sinith, G. H., and Robertson, D. C.: Thorax 21 : 545, 1966.

4. Neville, W. E., Colby, C., Peacock, H., and Kronowski, T. C.: Ann. Surg. 165: 206, 1967.

5. Hill, J. B.: Ann. New York Acad. Sciences 102: 108, 1962.

6. Schachter, D.: J. Lab. Clin. Med. 54: 763, 1959.

7. Hales, M. A., Williamson, R. J., and Heidenreich, W. F.: Surgery 41: 353, 1957.

8. Rand, P. W., Austin, W. H., and Chatterjee, M.: Surgery 53: 456, 1963.

9. Neville, W. E. and Talso, P. J.: Surgery 63: 220, 1968.

10. Dieter, R.A., Jr., Neville, W. E., and Pifarré, R.: J. Thorac. Cardiovasc. Surg. 59: 168, 1970.

11. Iliçin, G.: Hacettepe Bull. Med. Surg. (accepted for publication, in Turkish) 
12. Ebert, P. A., Jude, F. R., and Gaertner, R. A.: Girculation 31: 137, 1965.

13. Goswami, P.: Indian J. Med. Sci. 20: 206, 1966.

14. Liu, C. K., Lippman, M., Telfer, N., and Tam, C.: Clin. Res. 14: 161, 1966.

15. Krohen, B. G., Magidson, O., Lewis, R. R., Tsuji, H. K., Redington, J. U., and Kay, J. H.: J. Thorac. Cardiovasc. Surg. 56: 784, 1968.

16. Marcial, M. B., Vedoga, R. C., Zerbini, E.J., Verginelli, G., Bittencourt, D., and Amaral, R. G.: Am. J. Cardiol. 23: 400, 1969.

17. Mundth, E. D. and Austen, W. G.: Prog. Cardiovasc. Surg. 11: 229, 1968.

18. Scheinman, M. M., Sullivan, R. W., Hutchinson, J. C., and Hyatt, K. H.: Circulation 39: Suppl. I: 215, 1969.

19. Scheinman, M. M., Sullivan, R.W., Hutchinson, J. C., and Hyatt, K. H.: J. Thorac. Cardiovasc. Surg. 61: 135, 1971.

20. Larvor, P. and Durlach, J.: ler Symposium International sur le Déficit Magnésique en Pathologie Humaine, sous la direction de Durlach, .J., Paris, Vittel, 215, 1971.

21. Whang, R.: 1st International Symposium on Magnesium Deficit in Human Pathology, edited by Durlach, J., Paris, Vittel, p. 387, 1971.

22. Zumkley, H. and Losse, H.: Ite Internationales Symposion über der Magnesiummangel in der Menschlichen Pathologie, heraus gegeben von Durlach, J., Paris, Vittel, p. 327, 1971.

23. Welt, L. G.: Ist International Symposium on Magnesium Deficit in Human Pathology, edited by Durlach, J., Paris, Vittel, p. 347, 1971.

24. Martin, H. E., Mehl, J., and Wertman, M.: Med. Clin. North. Am. 36: 1157, 1962.

25. Seller, R.H., Ramirez, O., Brest, A. N., and Moyer, J. H.: Am. J. Ciardiol. 17: 786, 1966.

26. Kleiger, R. E., Seta, K., Vitale, J. J., and Lown, B.: Am. J. Cardiol. 17: 520, 1966.

27. Seller, R. H., Cangiano, J., Kim, K. E., Mendelssohn, S., Brest, A. N., and Swartz, G.: Am. Heart J. 79: 57, 1970.

28. Marx, R. and Hiller, C.: Klin. Wschr. 30: 71, 1952.

29. Anstall, H., Huntsman, R., Lehman, H., Hayward, G., and Weitzman, D.: Lancet i: 814, 1959.

30. Durlach, J.: Coeur. Med. Int. 6: 213, 1967.

31. Dupont, B., Pony, J. C., Le Bihan, G, and Leborgne, P.: Sem. Hôp. Paris 45: 3048, 1969.

32. Rotman, L.: 1st International Symposium on Magnesium Deficit in Human Pathology, edited by Durlach, J., Paris, Vittel, 239, 1971. 